\title{
Pregabalin does not affect fracture healing adversely
}

\author{
Pregabalin kırık iyileşmesini olumsuz etkilemez
}

\author{
Nizamettin Koçkara, MD., ${ }^{1}$ Hakan Sofu, MD., ${ }^{1}$ Ahmet Issin, MD., ${ }^{1}$ Mehmet Çetinkaya, MD, ${ }^{2}$ \\ Mahir Tayfur, MD., ${ }^{3}$ Bahadır Süleyman, MD. ${ }^{4}$ \\ ${ }^{1}$ Department of Orthopedics and Traumatology, Medical Faculty of Erzincan University, Erzincan, Turkey \\ 2Department of Orthopedics and Traumatology, Mengücekgazi Training and Research Hospital, Erzincan, Turkey \\ ${ }^{3}$ Department of Pathology, Medical Faculty of Erzincan University, Erzincan, Turkey \\ ${ }^{4}$ Department of Pharmacology, Medical Faculty of Erzincan University, Erzincan, Turkey
}

\begin{abstract}
Objectives: This study aims to assess the radiographic, histological, and biomechanical effects of pregabalin on fracture healing in a rat model of femur fracture.

Materials and methods: A total of 32 female WistarAlbino rats (mean age $12 \pm 1$ weeks; mean body weight $236 \pm 12$ grams) were randomized into four groups with eight rats in each group. Groups A and B were the control groups whereas $\mathrm{C}$ and $\mathrm{D}$ were the treatment groups. Drugs were delivered by oral gavage. Radiographic, histological and biomechanical evaluations were performed after sacrificing the rats in groups $\mathrm{A}$ and $\mathrm{C}$ on $15^{\text {th }}$ postoperative day and the rats in groups $\mathrm{B}$ and $\mathrm{D}$ on $30^{\text {th }}$ postoperative day.
\end{abstract}

Results: Although radiographic results were better in groups $A$ and $B$ than groups $C$ and $D$ at the end of $15^{\text {th }}$ day, no significant difference was detected at the end of $30^{\text {th }}$ day. No statistically significant differences were observed between the groups on $15^{\text {th }}$ and $30^{\text {th }}$ days in terms of histological or biomechanical evaluation.

Conclusion: Administration of pregabalin did not affect fracture healing process adversely in rats.

Keywords: Fracture healing; pharmaceutical preparations; pregabalin; rat model.

Patients treated surgically for a fracture in the daily clinical practice of traumatology may generally have regular medications for various systemic disorders. Several experimental studies testing the positive or negative effects of different drugs or chemicals on bone healing have been published in

\section{öz}

Amaç: $\mathrm{Bu}$ çalışmada sıçan femur kırı̆̆ pregabalinin kırık iyileşmesi üzerindeki radyolojik, histolojik ve biyomekanik etkileri değerlendirildi.

Gereç ve yöntemler: Toplam 32 dişi WistarAlbino sıçan (ort. yaş $12 \pm 1$ hafta; ort. vücut ağırlığ $236 \pm 12$ gram) her grupta sekiz sıçan olmak üzere dört gruba randomize edildi. Grup A ve B kontrol grupları iken grup C ve D tedavi grupları idi. İlaçlar oral gavaj yoluyla verildi. Grup A ve C'deki sıçanlar ameliyat sonrası 15. günde, grup B ve D'deki sıçanlar ameliyat sonrası 30. günde sakrifiye edildikten sonra radyolojik, histolojik ve biyomekanik değerlendirmeler yapıldı.

Bulgular: On beşinci gün sonunda grup A ve B'deki radyolojik sonuçlar grup C ve D'den daha iyi olmasına rağmen, 30. gün sonunda anlamlı farklılık saptanmadı. Histolojik ve biyomekanik değerlendirme açısından 15 . ve 30 . günlerde gruplar arasında istatistiksel olarak anlamlı farklılık gözlenmedi.

Sonuç: Pregabalin uygulanması sıçanlarda kırık iyileşmesi sürecini olumsuz etkilemedi.

Anahtar sözcükler: Kırık iyileşmesi; farmasötik müstahzarlar; pregabalin; sıçan modeli.

the literature. ${ }^{[1-3]}$ Pregabalin is a widely used drug for the treatment of diabetic peripheral neuropathy, postherpetic neuralgia, spinal cord-originated nerve pain, fibromyalgia, and neuropathic arthropathies. As an adjunct drug for reducing postoperative pain, it may also be administered in surgically treated

- Received: February 17, 2016 Accepted: June 07, 2016

- Correspondence: Nizamettin Koçkara, MD. Erzincan Üniversitesi Tıp Fakültesi Ortopedi ve Travmatoloji Anabilim Dalı, 24100 Erzincan, Turkey. Tel: +90 505 - 8296021 e-mail: nzmttn@yahoo.com 
patients. ${ }^{[4,5]}$ However, to the best of our knowledge, the effects of pregabalin on fracture healing have not been evaluated yet.

In this study, we aimed to assess the radiographic, histological, and biomechanical effects of pregabalin on fracture healing in a rat model of femur fracture.

\section{MATERIALS AND METHODS}

This study was conducted between December 2015 and January 2016 at Medical Faculty of Atatürk University and reviewed and approved by the Ethical Research Review Board of Erzurum Atatürk University. The study was conducted in accordance with the principles of the Declaration of Helsinki and the Guide for the Care and Use of Laboratory Animals. A total of 32 female Wistar-Albino rats (mean age $12 \pm 1$ weeks; mean body weight $236 \pm 12$ grams) were used for this experimental trial. All rats were fed in the laboratory for a week before the operation in order to make them adapted to the new environment. Five rats were housed in each cage and provided fresh water and chow ad libitum with a 12-12-hour light-dark cycle.

To create the fracture model, following general anesthesia induced by the intraperitoneal administration of ketamine $(50 \mathrm{mg} / \mathrm{kg})$, the rat was taken onto the operating table. Left thigh of the rat was prepared with povidone-iodine solution. A standard transverse fracture of the mid-diaphysis was created by using guillotine method. Then, the knee joint was incised and the patellar tendon displaced medially to expose the femoral condyles for the insertion of retrograde intramedullary Kirschner wire $(0.8 \mathrm{~mm}$ diameter steel K-wire). The intramedullary K-wire was advanced up to the trochanter major by using an electric drill to fix the fracture. The incisions were sutured and a single dose antibiotic prophylaxis was administered
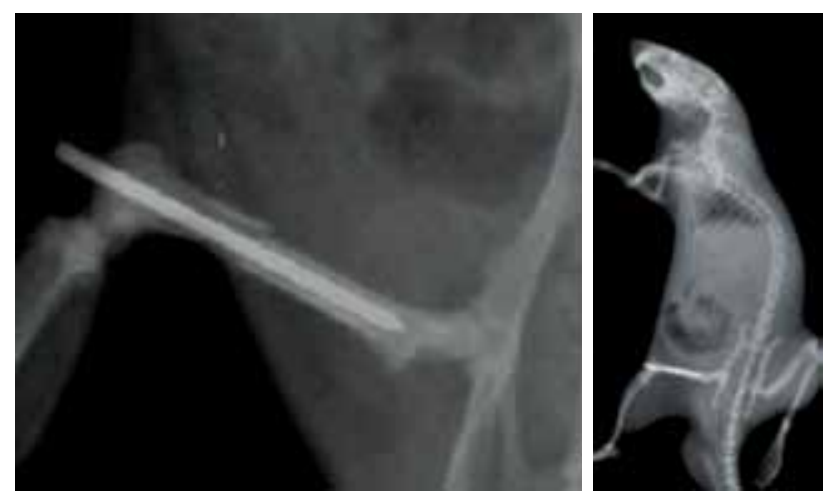

Figure 1. Radiographic confirmation of fracture and fixation. (cefazolin sodium, $5 \mathrm{mg}$ ). Fracture formation was confirmed radiographically (Figure 1).

The rats were randomized into four groups with eight rats included in each group. Groups $\mathrm{A}$ and $B$ were the control groups whereas C and D were the treatment groups. Drugs were delivered by oral gavage once a day beginning from the end of the fourth postoperative hour. The daily dosage of pregabalin for each rat in groups $C$ and $D$ was calculated according to body surface area conversion as equivalent the human dosing regimen of $150 \mathrm{mg} /$ day ${ }^{[6]}$ According to this method, the formula used in dose calculation was (Human Equivalent Dose $[\mathrm{mg} / \mathrm{kg}]=$ Animal Dose $[\mathrm{mg} / \mathrm{kg}]$ x Km factor for a mouse $/ \mathrm{Km}$ factor for a human). The rats in groups $\mathrm{A}$ and $\mathrm{B}$ were also administered $1 \%$ methylcellulose $(2 \mathrm{~mL} /$ day) by oral gavage in order to standardize stress factor between the control and treatment groups. Methylcellulose was chosen since it has no systemic effects and is one of the safest and most widely used vehicles available for administration via oral gavage. The rats in groups $A$ and $C$ were sacrificed via cervical dislocation after anesthetic (ketamine) administration at the end of the $15^{\text {th }}$ postoperative day, and the rats in groups $\mathrm{B}$ and $\mathrm{D}$ at the end of the $30^{\text {th }}$ postoperative day. After the rats were sacrificed, their left femurs were disarticulated from their hip and knee joints. Soft tissues on the femoral bone were dissected off gently from the bone without any damage to the callus tissue. The intact right femurs were also harvested for comparative mechanical testing.

\section{Radiographic evaluation}

Direct anteroposterior and lateral radiographic images of the sacrificed femurs were obtained at the $15^{\text {th }}$ and $30^{\text {th }}$ postoperative days. The radiographs were evaluated and the union status was classified according to the Lane and Sandhu grading system. ${ }^{[7]}$ Radiographic scoring was achieved by two of the authors and the lowest correlation coefficient was 0.90 .

\section{Histological evaluation}

The soft tissues covering the fractured femurs were dissected without removing the periosteum and the K-wire was carefully removed without any damage to the callus tissue. The femurs were fixed in $4 \%$ paraformaldehyde in phosphate buffered saline solution at $4{ }^{\circ} \mathrm{C}$ for two days before undergoing decalcification in $7 \%$ formic acid. Following decalcification process, specimens were then embedded in paraffin block and $7 \mu \mathrm{m}$ sections were cut. Hematoxylin and eosin stain was applied. Slides 

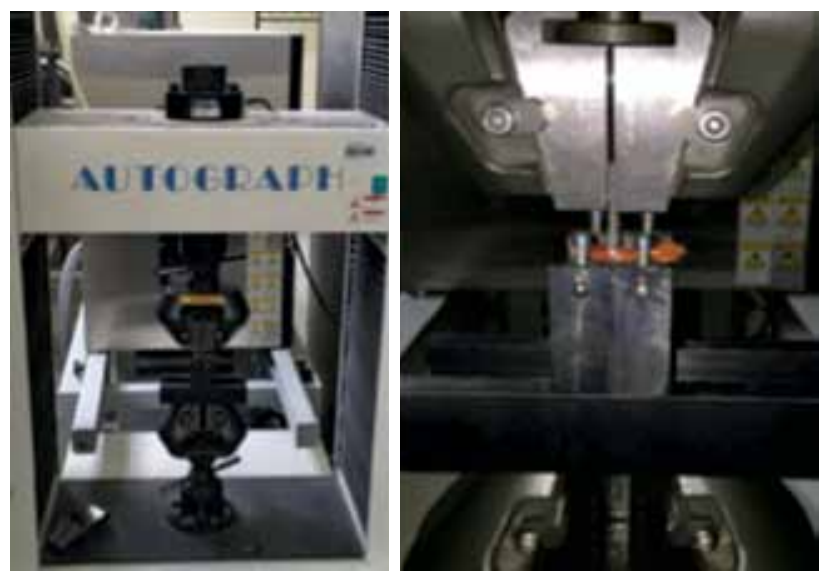

Figure 2. Fixation of fractured rat femur during mechanical testing.

were assessed under light microscope. The callus tissue was scored based on the system recommended by Huo et al. ${ }^{[8]}$

\section{Mechanical testing}

Following the dissection and disarticulation, the femurs were immediately wrapped in saline-soaked gauze, double-bagged and placed in a $-20{ }^{\circ} \mathrm{C}$ freezer. The night before mechanical testing, samples were thawed overnight in an $8{ }^{\circ} \mathrm{C}$ refrigerator. In order to determine the biomechanical behavior of test groups, three point bending tests were performed. The specimens were placed on the three point bending test apparatus in lateral direction as shown in Figure 2. The distance between the rollers was selected as $30 \mathrm{~mm}$ considering specimen sizes. A preload of $5 \mathrm{~N}$ for all specimens was applied before tests and then, the specimens were subjected to axial compressive forces until fracture occurred. The same procedure was repeated for all test groups. The biomechanical tests were performed by using a Shimadzu AG-IS Universal Testing Machine (Shimadzu Corporation, Tokyo, Japan) with a loading rate of $2 \mathrm{~mm} / \mathrm{minute}$ at room temperature. The applied forces and occurred displacements

\section{TABLE I}

Comparison of radiographic scores between control and treatment groups

\begin{tabular}{lcccc}
\hline \multirow{2}{*}{ Group } & Day 15 & & Day 30 & \\
\cline { 2 - 2 } & Mean \pm SD & & Mean $\pm S D$ & $p$ \\
\hline Control & $3.28 \pm 1.11$ & & $4.71 \pm 1.11$ & 0.032 \\
Treatment & $2.14 \pm 0.69$ & & $4.16 \pm 1.0$ & 0.002 \\
$p$ value & 0.043 & & 0.367 & \\
\hline
\end{tabular}

SD: Standard deviation. were recorded. Subsequently, maximum loads and axial stiffness values, which are the slope of linear portion of force versus displacement graph, were calculated and presented by using data analyses and related graphs.

\section{Statistical analysis}

Statistical analysis was performed with the Kruskal-Wallis test in intergroup comparisons, the Mann-Whitney $U$ test in pair group comparisons, and Fisher's exact tests in the comparison of qualitative data. Significance in the results was evaluated at the level of $p<0.05$. During the intervention, rats with evidence of fixation loss or infection were excluded and humanely euthanized.

\section{RESULTS}

We did not observe any complications related to anesthetics or oral drug administration. One rat in group A, one rat in group B, and two rats in group D were humanely euthanized due to infection at the end of $15^{\text {th }}$ postoperative day. Loss of fixation was diagnosed in one rat from group $\mathrm{C}$ and it was also euthanized. Therefore, the study was completed with seven rats in groups A, B, and C and six rats in group $D$. Three fractured femurs from each group underwent mechanical testing. Four femurs from groups $\mathrm{A}, \mathrm{B}$, and $\mathrm{C}$ and three from group $\mathrm{D}$ underwent histological evaluation.

At the end of $15^{\text {th }}$ postoperative day, radiographic scores were better in groups $\mathrm{A}$ and $\mathrm{B}$ than
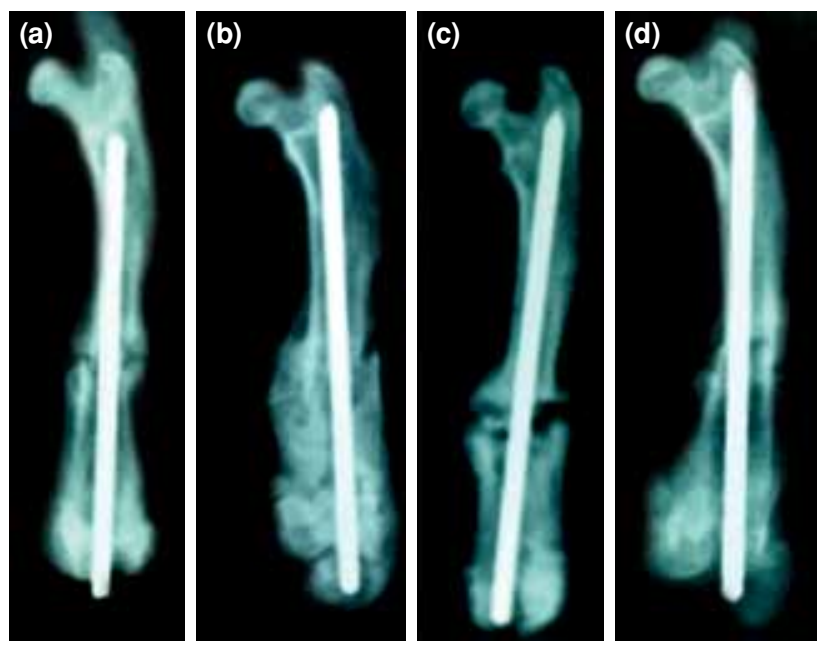

Figure 3. Radiographic progression of fracture healing. (a) Radiographic image of a fractured femur at $15^{\text {th }}$ day from group A. (b) Radiographic image of a fractured femur at $30^{\text {th }}$ day from group B. (c) Radiographic image of a fractured femur at $15^{\text {th }}$ day from group C. (d) Radiographic image of a fractured femur at $30^{\text {th }}$ day from group $D$. 

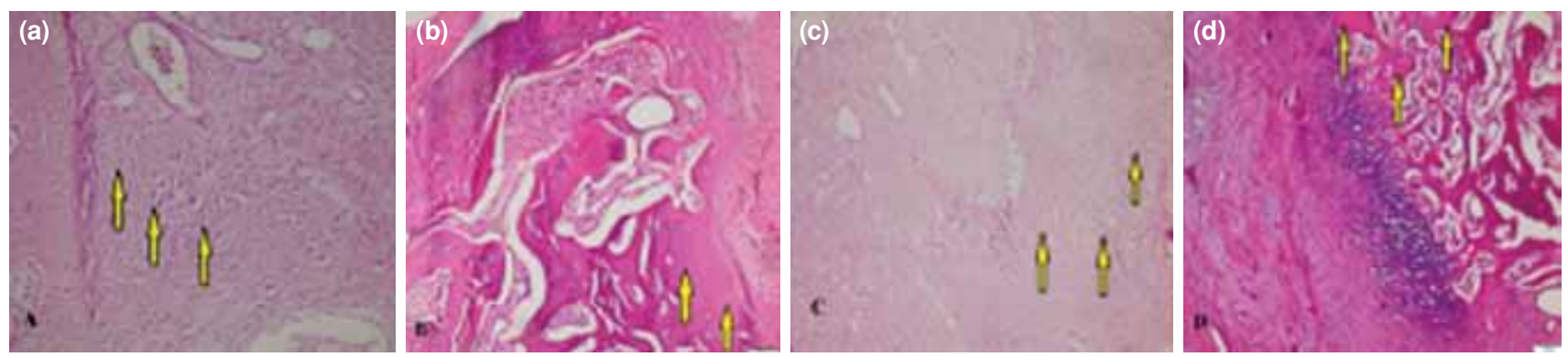

Figure 4. Histological progression of fracture healing. (a) Predominant cartilage tissue at $15^{\text {th }}$ day in a fractured femur from group A. (b) Immature bone with decreased cartilage tissue at $30^{\text {th }}$ day in a fractured femur from group B. (c) Wide area of fibrous tissue with less cartilage at $15^{\text {th }}$ day in a fractured femur from group C. (d) Immature bone with decreased cartilage tissue on central area at $30^{\text {th }}$ day in a fractured femur from group $D$.

in groups C and D ( $\mathrm{p}=0.043)$ (Table I). However, no statistically significant difference was detected between the groups at the end of $30^{\text {th }}$ day $(p=0.367)$ (Figure 3).

According to histological evaluation performed under a light microscope using hematoxylin and eosin staining, we did not detect any foreign body reactions, findings of histotoxicity or inflammation, or cortical bone necroses in neither groups A and B nor in groups $C$ and D. During the examinations, presence of fibrous tissue, cartilage tissue or immature bone was assessed according to the comparative evaluation of the specimens on the $15^{\text {th }}$ and $30^{\text {th }}$ days (Figure 4). However, no statistically significant differences were observed between the groups on the $15^{\text {th }}$ or $30^{\text {th }}$ days $(\mathrm{p}=0.434$ and $\mathrm{p}=0.458)$ (Table II).

Maximum force and stiffness values are presented in Figure 5a, b. From a biomechanical perspective, maximum force and stiffness can be considered as measures of resistance to deforming force, respectively. In this regard, the intact right femurs exhibited more strength than the fractured groups. However, we could not detect any significant difference of maximum force and stiffness between groups $\mathrm{A}$ and $\mathrm{B}$ and groups $\mathrm{C}$ and $\mathrm{D}$.

\section{TABLE II}

Comparison of histological scores between control and treatment groups

\begin{tabular}{lcccc}
\hline \multirow{2}{*}{ Group } & Day 15 & & Day 30 & \\
\cline { 2 - 2 } & Mean \pm SD & & Mean $\pm S D$ & $p$ \\
\hline Control & $4 \pm 0.81$ & & $7.14 \pm 0.69$ & $<0.001$ \\
Treatment & $3.71 \pm 0.48$ & & $6.83 \pm 0.75$ & $<0.001$ \\
$p$ value & 0.434 & & 0.458 & \\
\hline
\end{tabular}

SD: Standard deviation.

\section{DISCUSSION}

The fracture healing process has not yet been completely elucidated, and it still remains as one of the most important topics in the field of orthopedics. ${ }^{[9]}$ It is a cascade of complex biological events which has been demonstrated to be influenced by a variety of local and systemic factors. ${ }^{[10]}$ Parallel to the development and increasing numbers of new drugs on the market, experimental studies continue to be the main tools providing basic information about the effects of those drugs on several processes related to different organ systems such as fracture healing. To the best of our knowledge, the radiographic, histological, and biomechanical effects of pregabalin on fracture healing have not been discussed in the literature yet.

Pregabalin is a relatively new drug that has a wide range of indications. It has also been reported to show analgesic activity in various animal models. ${ }^{[11,12]}$ In their study assessing the analgesic effect of pregabalin in orofacial rat models of acute inflammatory pain and of persistent pain associated with nerve injury and cancer, Hummig et al. ${ }^{[12]}$ concluded that it produced a marked antinociceptive effect. In a randomized, double-blind, placebocontrolled clinical trial, Clarke et al. ${ }^{[4]}$ mentioned that perioperative administration of pregabalin decreased opioid consumption in hospital and reduced daily pain scores and adjunct opioid consumption for one week after discharge following total hip arthroplasty. Sarıtaş et al. ${ }^{[13]}$ tested the effects of pregabalin on wound healing in a rat model and reported that inflammation scores were significantly lower and wound healing was significantly better in the control group when compared with treatment group until day 13. Similarly, in our study, the radiographic scores at $15^{\text {th }}$ day after fracture were better in control group. Our findings demonstrated that pregabalin may negatively affect the healing process at the 
(a)

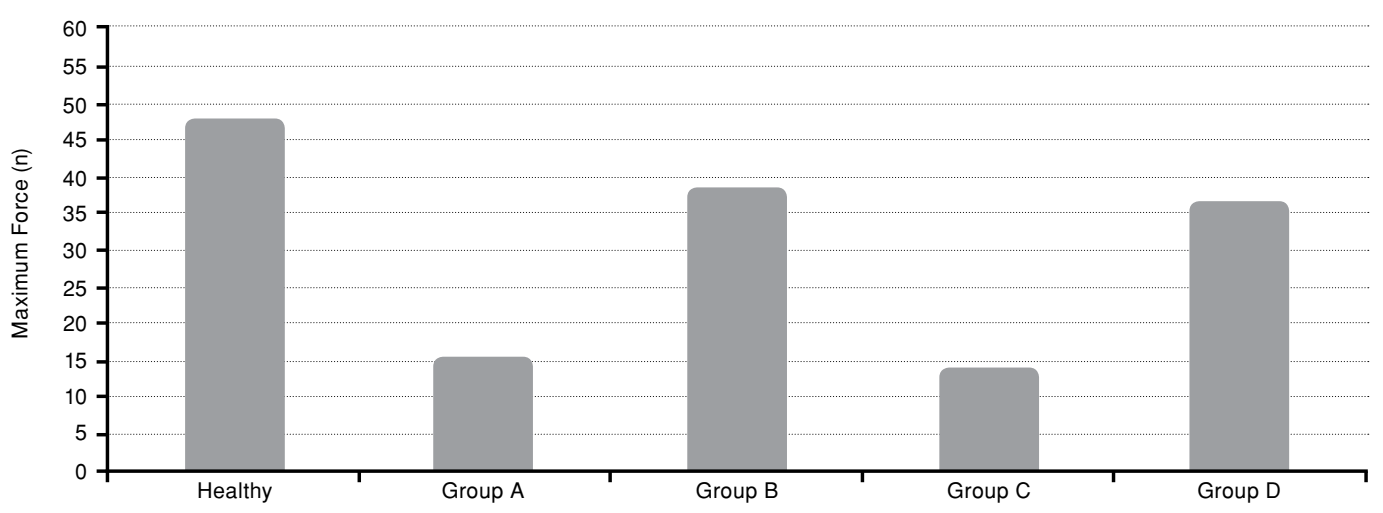

(b)

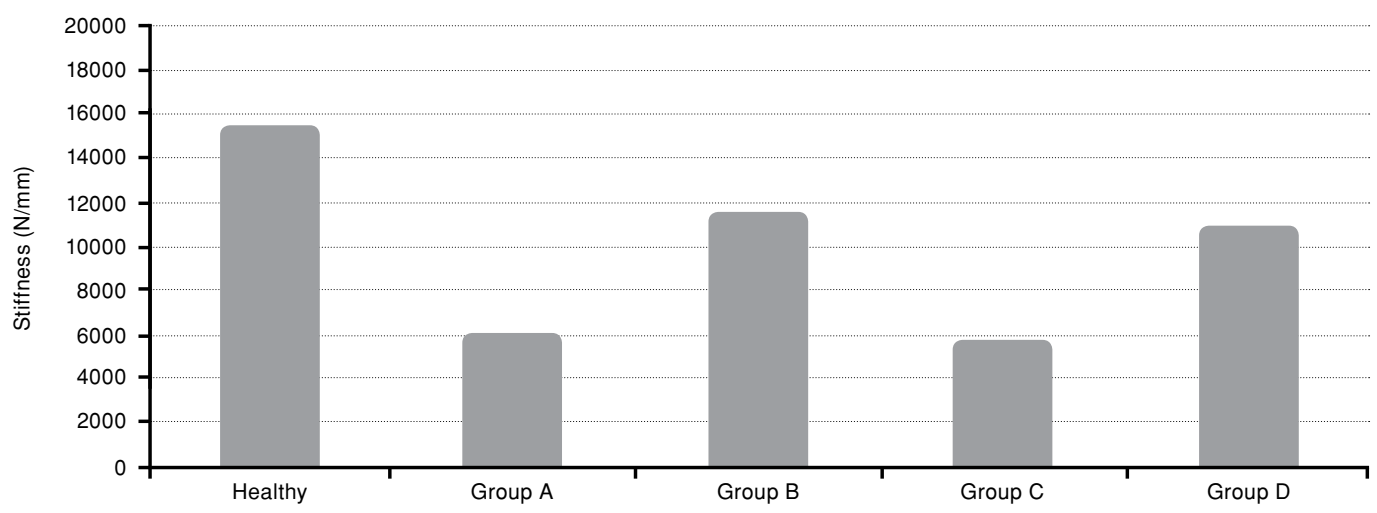

Figure 5. (a, b) Maximum force and stiffness values of intact femurs and fractured femurs.

first stages. However, no statistically significant difference was observed at the end of the $30^{\text {th }}$ day. Although the radiographic scores at $15^{\text {th }}$ day after fracture were better in control group when compared to treatment group, the $\mathrm{p}$ value was 0.043 which was very close to the significance level of 0.05 and thus lead us question its clinical importance. Additionally, we did not observe any significant negative effects of pregabalin on histological progression of the fracture healing in comparison to control group. Biomechanical strength of the femurs at the end of $30^{\text {th }}$ day was also similar between the control and treatment groups.

The standardized experimental fracture healing model used in this study has been widely used in the literature..$^{[1,9,14]}$ The dosage of drug administration was calculated according to body surface area conversion recommended as the standard way to approximate equivalent exposure of drugs among different kinds of animals. ${ }^{[6]}$ Additionally, administration of $1 \%$ methylcellulose ( $2 \mathrm{~mL} /$ day) by oral gavage in control group standardized the stress factor for all rats. We applied biomechanical testing of the intact right femurs, and fractured left femurs with or without pregabalin treatment to achieve the best objective comparison in the aspect of stiffness.

However, the major limitation of the present study was the limited number of rats included in each group. The study was started with eight rats included in each of the four groups and data analysis included seven rats in three groups and six rats in one group. As a second limitation, we did not make any comparison based on the serum levels of cytokines and bone markers.

In conclusion, the data we acquired during this study demonstrated that the administration of pregabalin may affect the fracture healing process in a negative manner initially but the results at the end have been found to be similar between the treatment and control groups. Although the results of experimental animal studies cannot be directly adapted to daily clinical practice; the data of the present study may provide orthopedic surgeons the basic information regarding the usage of pregabalin 
when treating a fracture. Further experimental and clinical trials are required to confirm our findings.

\section{Declaration of conflicting interests}

The authors declared no conflicts of interest with respect to the authorship and/or publication of this article.

\section{Funding}

The authors received no financial support for the research and/or authorship of this article.

\section{REFERENCES}

1. Aydin K, Sahin V, Gürsu S, Mercan AS, Demir B, Yildirim T. Effect of pentoxifylline on fracture healing: an experimental study. Eklem Hastalik Cerrahisi 2011;22:160-5.

2. Toğral G, Arıkan M, Korkusuz P, Hesar RH, Ekşioğlu MF. Positive effect of tadalafil, a phosphodiesterase- 5 inhibitor, on fracture healing in rat femur. Eklem Hastalik Cerrahisi 2015;26:137-44.

3. Göçer H, Önger ME, Kuyubaşı N, Çıraklı A, Kır MÇ. The effect of teicoplanin on fracture healing: an experimental study. Eklem Hastalik Cerrahisi 2016;27:16-21.

4. Clarke H, Pagé GM, McCartney CJ, Huang A, Stratford $\mathrm{P}$, Andrion J, et al. Pregabalin reduces postoperative opioid consumption and pain for 1 week after hospital discharge, but does not affect function at 6 weeks or 3 months after total hip arthroplasty. $\mathrm{Br} \mathrm{J}$ Anaesth 20150;115:903-11.

5. Lam DM, Choi SW, Wong SS, Irwin MG, Cheung CW. Efficacy of Pregabalin in Acute Postoperative Pain Under Different Surgical Categories: A Meta-Analysis. Medicine
(Baltimore) 2015;94:1944.

6. Reagan-Shaw S, Nihal M, Ahmad N. Dose translation from animal to human studies revisited. FASEB J 2008;22:659-61.

7. Lane JM, Sandhu HS. Current approaches to experimental bone grafting. Orthop Clin North Am 1987;18:213-25.

8. Huo MH, Troiano NW, Pelker RR, Gundberg CM, Friedlaender GE. The influence of ibuprofen on fracture repair: biomechanical, biochemical, histologic, and histomorphometric parameters in rats. J Orthop Res 1991;9:383-90.

9. Aydin A, Halici Z, Akoz A, Karaman A, Ferah I, Bayir $Y$, et al. Treatment with $\alpha$-lipoic acid enhances the bone healing after femoral fracture model of rats. Naunyn Schmiedebergs Arch Pharmacol 2014;387:1025-36.

10. Einhorn TA, Gerstenfeld LC. Fracture healing: mechanisms and interventions. Nat Rev Rheumatol 2015;11:45-54.

11. Tuchman M, Barrett JA, Donevan S, Hedberg TG, Taylor CP. Central sensitization and $\mathrm{Ca}(\mathrm{V}) \alpha_{2} \delta$ ligands in chronic pain syndromes: pathologic processes and pharmacologic effect. J Pain 2010;11:1241-9.

12. Hummig W, Kopruszinski CM, Chichorro JG. Pregabalin reduces acute inflammatory and persistent pain associated with nerve injury and cancer in rat models of orofacial pain. J Oral Facial Pain Headache 2014;28:350-9.

13. Sarıtaş TB, Korkmaz M, Sevimli A, Sarıtaş ZK. Comparison of the effects of gabapentin and pregabalin on wound healing in rats. Int Wound J 2016;13:748-53.

14. Oktaş B, Orhan Z, Erbil B, Değirmenci E, Ustündağ N. Effect of extracorporeal shock wave therapy on fracture healing in rat femural fractures with intact and excised periosteum. Eklem Hastalik Cerrahisi 2014;25:158-62. 